\title{
ヒト皮膚から放散するアセトアルデヒドの室内空気中濃度に及ぼす影響
}

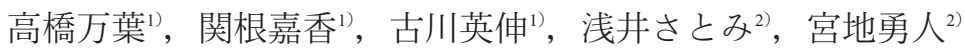 \\ ${ }^{1)}$ 東海大学大学院理学研究科化学専攻 干259-1292 神奈川県平塚市北金目4-1-1 \\ 2)東海大学医学部基盤診療学系臨床検查学 ₹259-1193 神奈川県伊勢原市下糟屋143
}

\section{Influence of acetaldehyde emanating from human skin on indoor air concentration level}

\author{
Kazuyo TAKAHASHI ${ }^{1)}$, Yoshika SEKINE ${ }^{1)}$, Hidenobu FURUKAWA $^{1)}$, Satomi ASAI ${ }^{2)}$ and \\ Hayato MIYACHI \\ ${ }^{1)}$ Graduate School of Science, Tokai University, 4-1-1 Kitakaname, Hiratsuka, Kanagawa, 259-1292, Japan \\ ${ }^{2}$ School of Medicine, Tokai University, 143 Shimokasuya, Isehara, Kanagawa, 259-1193, Japan
}

要 旨

室内空気中のアセトアルデヒドの発生源执よび発生機構については不明な点が多い。本研究では，これま で考慮されてこなかったヒト皮膚表面から放散するアセトアルデヒドの室内空気中濃度に及ぼす影響につい て，パッシブ・フラックス・サンプラー法による健常人ボランティアを対象とした放散フラックスの実測に 基づき検討した。その結果，ヒト皮膚由来のアセトアルデヒドの放散速度は，飲酒後の呼気に由来するアセ トアルデヒドの放散速度よりあ大きく，呼気よりあ重要な発生源であることがわかった。居室の在室者 1 名 を想定した場合，皮膚由来のアセトアルデヒドは，室内濃度指針值レベル $\left(48 \mu \mathrm{g} \mathrm{m}^{-3}\right)$ に対しては $0.87 \sim 2.3$ \%の寄与であったが，飲酒を伴う場合は居室の臭気源になる可能性が示唆された。在室者が複数いる場合に は，皮膚からの放散速度は無視できないほど大きな寄与を示す可能性があり，皮膚ガスは新たに着目すべき 発生源の一つとなる可能性が示唆された。

\begin{abstract}
Acetaldehyde is known as one of the indoor environmental contaminants, and numerous emission sources have been reported. However, little consideration has been given to the influences of human skin gas on the indoor air concentration. This study aimed to estimate the contribution of human skin gas on the indoor air concentration levels of acetaldehyde based on the measurement of emission flux of acetaldehyde from human skin of volunteers using passive flux sampler methodology. As a result, emission rate of acetaldehyde from human skin of a single resident was much greater than that from human breath even after drinking alcohol. Although contribution of the human skin was estimated only $0.87 \sim 2.3 \%$ of indoor air quality guideline level $\left(48 \mu \mathrm{g} \mathrm{m}^{-3}\right)$, the skin gas after drinking was suggested to be a source of odor of a room. These results lead a conclusion that human skin gas should be considered as an important emission source of acetaldehyde in indoor air, when occupied with more than drunk one person.
\end{abstract}

Key words: 皮膚ガス (Human skin gas)，アセトアルデヒド(Acetaldehyde)，室内空気中濃度 (Indoor air concentration), 放散速度 (Emission rate)，パッシブ・フラックス・ サンプラー(Passive Flux sampler)

\section{1. 緒言}

臨床検査において，多様な疾患の治療扔よび診断 のために, 血液以外の生体サンプル（例えば，尿， 汗, 呼気, 唾液など)の利用が進められている。こ れらのサンプルは採取時に痛みを伴わず(非侵襲), また出血することなく(非観血)採取可能な生体サン プルであり，検査にあたって提供者の同意を得られ やすい，感染症の恐れがない，など様々な利点があ

受付：2013年2月14日（Received: 14 February 2013）

受理：2013年4月1日（Accepted: 1 April 2013）
$ろ^{1-4)}$ 。このような非侵襲・非観血的な生体サンプル として，ヒトの皮膚表面から放散する微量なガス (皮膚ガス)が新たに注目されている。

皮膚ガスは，呼気や腸内ガスと同様に生体ガスの 一つであり, 皮膚表面から(1)血液から揮発して直 接放散，（2）血液から汗腺を経由して放散，（3）皮膚 表面で生成して放散するガスと考えられている。生 体内での代謝由来のガスは(1)や(2)の経路, 皮膚表 面の常在菌の働きや皮膚成分の化学反応で生じるガ スは(3)の経路が重要である。Bernier $ら^{5,6)}$ は, 手掌 
でガラスビーズをこすり，ガラスビーズに付着した 化学成分をガスクロマトグラフ/質量分析計により 定性・定量分析し，303種類を同定した。Tsudaらの 研究グループ7-9) は, 皮膚表面または指や手を挿入し たバッグ内にキャリアーガスを導入し，直接または 濃縮過程を経てガスクロマトグラフ装置等に導入し, キャリアーガス中のアンモニア, メタン, エタン, エチレン, 水素, アセトンおよび一酸化炭素等の定 量分析に成功し, 呼気中濃度との関係を考察してい る。従来から行われている呼気分析では, 呼気量に よって対象ガス濃度が変わる可能性が指摘されてい る。そこで筆者らは, 皮膚ガスの特性に着目し, 一 定面積の皮膚から単位時間当たりに放散されるガス の質量, すなわち放散フラックス $\left(\mathrm{ng} \mathrm{cm}^{-2} \mathrm{~h}^{-1}\right)$ を簡 便に測定することを着想し，建材表面から放散され る揮発性有機化合物の測定に開発されたパッシブ・ フラックス・サンプラー (Passive Flux Sampler, PFS) 法 ${ }^{10)}$ を参考に, 皮膚から放散されるカルボニル 化合物 (ホルムアルデヒド, アセトアルデヒド, ア セトン)の受動的測定法を開発し ${ }^{11)}$ ，ヒトの生理的・ 身体的条件之皮膚ガス放散フラックスの関係につい て臨床データを積み重㸚てきた。

一方, 皮膚ガスの中で臭気閾值の低い成分はいわ ゆる体臭を構成し, 居室の臭気や空気污染の原因々 なることが指摘されている。しかし体臭の化学成分 が，居室の室内濃度に与える影響については定量的 に明らかになっていない。アセトアルデヒドは，皮 膚ガスの化学成分の一つであり, 臭気物質としても 知られている(社団法人に打い・か抢り環境協会が 提示する臭気閾值は2.7 $\left.\mu \mathrm{g} \mathrm{m}^{-3}\right)^{12)}$ 。またシック八 ウス症候群や化学物質過敏症の原因物質の一つ之考 えられており, 厚生労働省では室内濃度指針値とし て48 $\mu \mathrm{g} \mathrm{m}^{-3}$ を設定し, この值は日本建築学会では 室内空気中濃度規準としても採用されている ${ }^{13}$ 。

室内環境中のアセトアルデヒドの発生源は多種多 様であり, 一部の木質系建築材料からの直接放散, 酢酸ビニル系接着剂を用いた建築材料からの放散, エチルアルコールの酸化に伴う二次生成, テルペン 類とオゾンの反応による二次生成, 呼気などが報告 されている。中西ら ${ }^{14)}$ は住宅建材 (木材, 接着剂, 塗料溶剂), 家具 (木材, 塗料溶剂), 趣味(接着剂), 燃焼系暖房機器, 調理用機器, 喫煙, 飲酒 (呼気), 二次生成㧍よび屋外大気に着目し，これら既知の発 生源からの放散量を積み上げて室内空気中濃度を推
定したところ, 一般住宅に打ける実測值の算術平均 值 $\left(27 \mu \mathrm{g} \mathrm{m}^{-3}\right)$ を十分に説明できず, 未知未確認の 発生源が存在する可能性を示唆した。

そこで本研究では，これまで室内環境中のアセ卜 アルデヒドの発生源として考慮されてこなかった皮 膚ガスに着目し，PFSによる実測に基づき，ヒト皮 膚由来のアセトアルデヒドが室内空気中濃度に及ぼ す影響を定量的に検討した。

\section{2. 方法}

本研究では, ヒト皮膚から放散されるアセトアル デヒドの放散フラックス $E\left(\mathrm{ng} \mathrm{cm}^{-2} \mathrm{~h}^{-1}\right)$ の実測值を 用い, これにヒト一人あたりの皮膚の露出面積 $S$ $\left(\mathrm{cm}^{2}\right)$ を乗じて放散速度 $M\left(\mu \mathrm{g} \mathrm{h}^{-1}\right)$ を求め, この放 散速度, 想定した居室の容積 $V\left(\mathrm{~m}^{3}\right)$ おょび換気回数 $N\left(\mathrm{~h}^{-1}\right)$ より定常状態を仮定して室内空気中濃度 $(\mu \mathrm{g}$ $\mathrm{m}^{-3}$ )を推定した。計算シナリオとして, はじめに健 常人ボランティア 60 名を対象に一斉測定した結果を 用いた場合, 次に飲酒を伴いアセトアルデヒド放散 フラックスが増加した場合について検討した。以下 にその手順を示す。

\section{1 健常人60名の放散フラックスを用いた室内空 気中濃度の推定}

Sekine et al. ${ }^{11}$ は健常人ボランティア 60 名 (男性46 名, 女性14名, 年齢19〜23歳)を対象にPFS法によ りアセトアルデヒド放散フラックスを測定した。測 定值は対数正規分布で近似でき, 検出下限值 (LOD) 未満の值については $1 / 2$ LODを用いて幾何平均值士

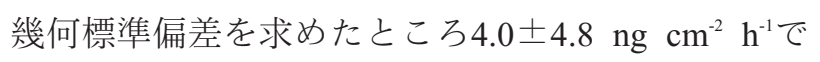
あった。測定值には, 性差や年齢差は見られなかっ たため ${ }^{11}$, これらの值を放散フラックスEの基礎デー タとして採用した。

男性抢よび女性の体表面積 $B\left(\mathrm{~cm}^{2}\right)$ には, 蔵澄ら のデータを採用し, 男性16869土1292 $\mathrm{cm}^{2}$ (正規分 布), 女性 $15331 \pm 1190 \mathrm{~cm}^{2}$ (正規分布)を基礎デー夕 とした。一方, 皮膚ガスの放散は着衣によって遮蔽 されると仮定し, 皮膚の露出割合 $R(-)$ を設定した。 この設定に当たり, 夏季および冬季に男性もしくは 女性の在室者はFig.1に示すような服装をしている ことを想定し，小野らの熱傷面積に関する報告 ${ }^{16}$ を 参考に露出割合を決定し, 夏季は男女ともに $R=$ 0.51 , 冬季は男女と屯に 0.21 とした。衣服に覆われ ていない皮膚の露出面積 $S\left(\mathrm{~m}^{2}\right)$ は, 体表面積 $B$ と露 

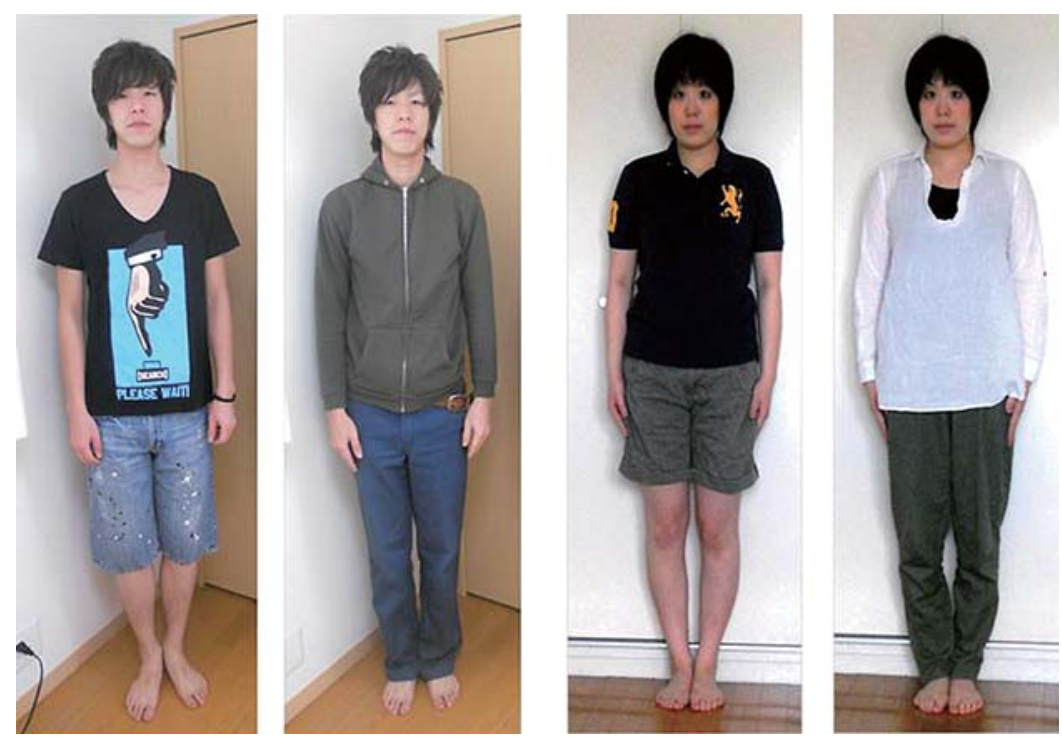

Fig.1 Typical clothes of volunteers in summer and winter for the estimation of skin area exposed to the indoor air

出割合 $R$ の積であり, 在室者1名の皮膚表面から放 散するアセトアルデヒド放散速度 $M\left(\mu \mathrm{g} \mathrm{h}^{-1}\right)$ を(1)式 から推定した。

$$
M=E \cdot B \cdot R \cdot 10^{-3}=E \cdot S \cdot 10^{-3}
$$

放散速度 $M$ を推定するにあたり, 放散フラックス $E$, 男女それぞれの体表面積 $B$ はそれぞれ固有の分 布を有することから，それぞれの分布に従う乱数を 10,000個発生させ，モンテカルロ・シミュレーショ ンにより放散速度 $M$ の頻度分布を求めた。乱数発生 には，マイクロソフト社Excel ${ }^{\circledast}$ Ver.14.0.6129.5000 の分析ッールを使用した。

得られた放散速度 $M$ の幾何平均值 $M_{\mathrm{g} \text { manan, }}$, 換気回 数 $N\left(\mathrm{~h}^{-1}\right)$ お よび部屋の内容積 $V\left(\mathrm{~m}^{3}\right)$ から, 完全混合 された定常状態を仮定し, 室内空気中アセトアルデ ヒド濃度 $C\left(\mu \mathrm{g} \mathrm{m}^{-3}\right)$ を算出した。

$$
C=\frac{M_{g . m e a n}}{N \cdot V}
$$

室内条件は一般住宅居室を想定し, 中西 ${ }^{16)}$ の推 定条件にあわせて, 換気回数は $0.6 \mathrm{~h}^{-1}$, 部屋の内容 積は $32 \mathrm{~m}^{3}$ とした。

\section{2 飲酒に伴い放散フラックスが増加した場合の 推定}

健常人ボランティアを対象に飲酒後のアセトアル デヒド放散フラックスを測定し, 室内空気中濃度へ の寄与率を推定した。

\section{2.1 被験者および実験条件}

被験者は健常人ボランティアとして男女 8 名 (男性 4名：21歳〜24歳, 女性 4名：21歳〜24歳) とした。 な打被験者は事前にアルコールパッチテストを行い, アセトアルデヒド脱水素酵素(ALDH2) 不活性型が 4名, ALDH2 低活性型が1名, ALDH2活性型が3名 であった。飲酒実験は2010年7月16日〜17日に実施 した。皮膚ガスは飲酒3時間前から飲酒14時間後ま で1〜2時間間隔で捕集した。捕集部位は前前腕部に て行った。な找被験者は室内空気中のアセトアルデ ヒドが皮膚に付着する影響を除外するため長袖を着 用した。食事は昼食, 夕食は全員同じ食事をとり, 測定期間中は水のみ摂取可とした。飲酒行為として, 市販のリキュール(アルコール分5\%, 発泡性 350 $\mathrm{mL}$ )を夕食直後に摂取した。

これとは別に, 飲酒前にさらにウコン入り飲料水 を飲料した場合について，2010年7月23日〜24日に 別途実施した。被験者は先の健常人ボランティアと 同一であり，市販のウコン飲料水 $(100 \mathrm{~mL}$, クルク ミン30 mg含む)を飲酒前に摂取する以外は, すべ て同一の条件で行った。

本研究は東海大学湘南校舎「七卜を対象とする研 
究」倫理委員会の承認を得て実施した。

\section{2.2 試薬}

アセトアルデヒドの捕集剤として，2,4-ジニト ロフェニルヒドラジン $(\mathrm{DNPH})$ (関東化学，特級) 扔 よびリン酸(関東化学，特級， $85.0 \%$ )を用いた。ま た高速液体クロマトグラフィー（HPLC）の溶離液に はHPLC用アセトニトリル(関東化学，99.8\%)を用 いた。なお検量線用の標準溶液にはHPLC用 16 種 DNPH混合標準溶液(各10 $\mu \mathrm{g} \mathrm{mL}^{-1}$ アセトニトリル 溶液, 和光純薬)の希釈系列を用いた。また，捕集 フィルターを洗浄する際は過酸化水素水(和光純薬, $30.0 \%)$ を用いた。

\section{2. 3 PFSの作製}

PFSは小型, 軽量, 電力不要のポータブルデバイ スであり，Fig.2に示すように，ステンレス製メン 夕ム缶(直径 $3.9 \mathrm{~cm}$, 高さ $0.9 \mathrm{~cm}$ ), PTFE製プレー 卜 $(36 \mathrm{~mm} \phi)$, 捕集フィルターおよびO-リングか らなる。捕集フィルターはO-リングで固定されて いる。このPFSを一定時間皮膚表面上に固定し，皮 膚から放散し, 空間内を拡散する対象成分を捕集フィ ルターで捕捉する。捕集フィルターは，セルロース 万紙(Advantec，No.51A， $36 \mathrm{~mm} \phi ， 0.18 \mathrm{mmt}$ )に0.2 $\% \mathrm{DNPH}-1 \%$ リン酸/アセトニトリル溶液をDipping法 により含浸し，デシケーター内で真空乾燥して作製 した。セルロースろ紙はあらかじめ $2 \%$ 過酸化水素 水に浸し蒸留水で洗浄し真空乾燥したものを用いた。

\section{2.4 捕集および分析方法}

PFSを被験者の左前前腕部にあて, 皮膚ガスを 1 時間捕集した。試料ブランクとして, 同時にPFS をガラスシャーレにかぶせ, PFSの内空間に存在す る空気中の対象物を捕集した。捕集後，捕集フィル ターからDNPH誘導体をアセトニトリル $10 \mathrm{~mL}$ で抽 出し, HPLCにより定量した。得た捕集量 $W(\mathrm{ng})$ と 捕集時間 $t(\mathrm{~h}), \operatorname{PFS}$ の捕集面積 $S^{\prime}\left(\mathrm{cm}^{2}\right)$ を用いてアセ トアルデヒド放散フラックス $E\left(\mathrm{ng} \mathrm{cm} \mathrm{cm}^{-2} \mathrm{~h}^{-1}\right)$ 求めた。 PFSの捕集面積 $S^{\prime}$ は7.79 $\mathrm{cm}^{2}$ であった。

$$
E=\frac{W}{S^{\prime} \cdot t}
$$

用いたHPLCの構成は次の通りである。ポンプ: Hitachi L-2130型, 紫外線吸収検出器 : Hitachi L2400型, カラム : GL Science, Inertsil-ODS80A, 5 $\mu \mathrm{m}, 4.6 \mathrm{~mm} \times 150 \mathrm{~mm}$, 溶離液: アセトニトリル :

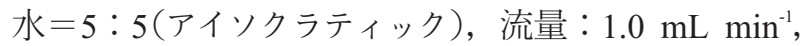
波長：360 nm, 注入量：20 $\mu \mathrm{L}$ 。

PFSによるアセトアルデヒドの測定性能は既報に 記した通りであるが，添加回収率は $101 \pm 0.50 \%$ $(n=3)$, 繰り返し捕集再現性は捕集量 $0.27 \mu \mathrm{g}$ に対 して $8.3 \%(n=5)$, 検出下限值はブランク值の標準 偏差の3倍 $\left(3 \sigma_{\mathrm{b}}\right)$ で定義し, 捕集時間1日間の場合 $0.85 \mathrm{ng} \mathrm{cm}^{-2} \mathrm{~h}^{-1}$ であった。

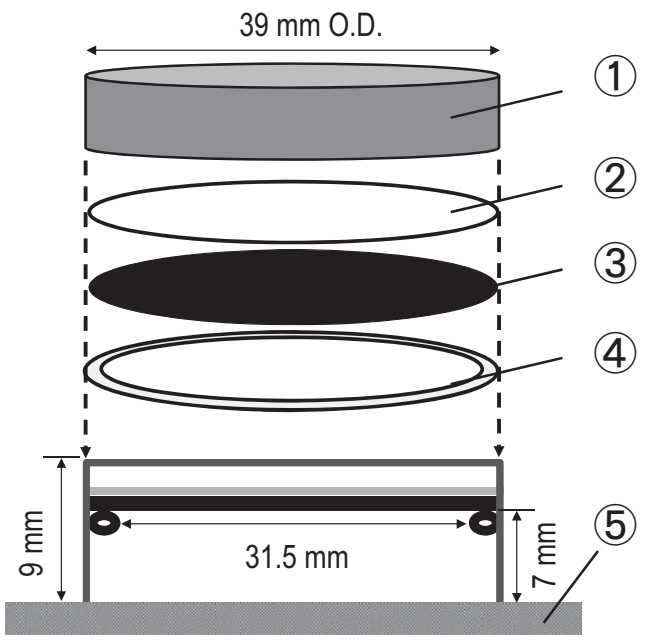

(1) Stainless Petri dish (2)PTFE plate (3)Trapping filter (4)PTFE O-ring (5)Human skin

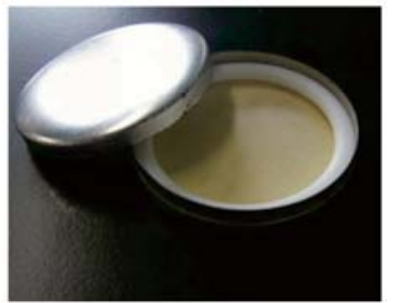

Overview of the PFS

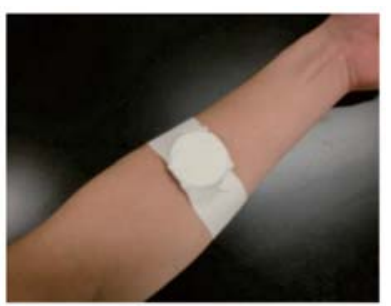

Sampling from forearm

Fig.2 Schematic view of the passive flux sampler for the trapping of acetaldehyde emanating from human skin 


\section{2.5 室内濃度及ぼす影響}

2. 2. 4 で得られた被験者 8 名の放散フラックス $E\left(\mathrm{ng} \mathrm{cm} \mathrm{ch}^{-2} \mathrm{~h}^{-1}\right)$ の平均值を測定時毎に求め, 飲酒に 伴う放散フラックスの増加率を算出し, この増加率 を2.1で求めた皮膚ガス中アセトアルデヒド放散速 度に乗じて室内空気中濃度に及ぼす飲酒の影響を推 定した。

\section{3. 結果および考察}

夏季服装㧍よび冬季服装で男性または女性1名の 皮膚から放散されるアセトアルデヒドの放散速度の 分布をFig.3に示す。夏季は露出面積が大きいため, 冬季に比べると男女ともに放散速度の分布が広くな ることがわかる。また体表面積の大きい男性の方が, 女性に比べて放散速度が大きくなった。得られた放 散速度の分布は, 対数正規分布で近似できたことか ら，それぞれの分布に抢ける幾何平均值士幾何標準 偏差を求めた。その結果, 放散速度は, 夏季・男性 1名では21 $2.6 \mu \mathrm{g} \mathrm{h}^{-1}$, 夏季・女性1名では $19 \pm 2.8$ $\mu \mathrm{g} \mathrm{h}^{-1}$, 冬季・男性1名では8.8 $2.6 \mu \mathrm{g} \mathrm{h}^{-1}$, 冬季・ 女性1名では $8.0 \pm 2.6 \mu \mathrm{g} \mathrm{h}^{-1}$ となった。これら皮膚 からのアセトアルデヒド放散速度の幾何平均值を,
室内の他の主要な発生源からの放散速度 ${ }^{14)}$ と比較し てFig.4に示す。最も高い值を示した夏季・男性の 皮膚からの放散速度は, 飲酒後の呼気からの放散速 度の 1.8 倍程度であり, 呼気よりも重要な発生源で ある可能性が見いだされた。しかし，家具や木質系 建築材料からの放散速度に比べて低水準であった。

ここで得られた放散速度の幾何平均值を用いて, 一般住宅の居室にヒトが1名在室しているとき, 皮膚 ガス由来のアセトアルデヒドが室内で完全混合され たと仮定した場合の室内空気中アセトアルデヒド濃 度を推定した結果, 夏季・男性1名では1.1 $\mu \mathrm{g} \mathrm{m}^{-3}$, 夏季・女性1名では $1.0 \mu \mathrm{g} \mathrm{m}^{-3}$, 冬季・男性1名では $0.46 \mu \mathrm{g} \mathrm{m}^{-3}$, 冬季・女性1名では $0.42 \mu \mathrm{g} \mathrm{m}^{-3}$ となっ た。得られた室内空気中濃度は厚生労働省の室内濃 度指針值 (48 $\left.\mu \mathrm{g} \mathrm{m}^{-3}\right)$ ) 0.87 2.3\%に相当した。ま た皮膚ガスの寄与濃度は, 中西らが集計した一般住 宅における実測值の平均値 $\left(27 \mu \mathrm{g} \mathrm{m}^{-3}\right)$ の $1.6 \sim 4.0 \%$ に相当し, 既知の発生源からの寄与濃度の総和 (14.3 $\left.\mu \mathrm{g} \mathrm{m}^{-3}\right)$ と合わせても実測值を説明できるレベルでは なかった。

Fig.5(a)は，被験者8名が飲酒した場合のアセト アルデヒド放散フラックスの経時变化を示す。飲酒
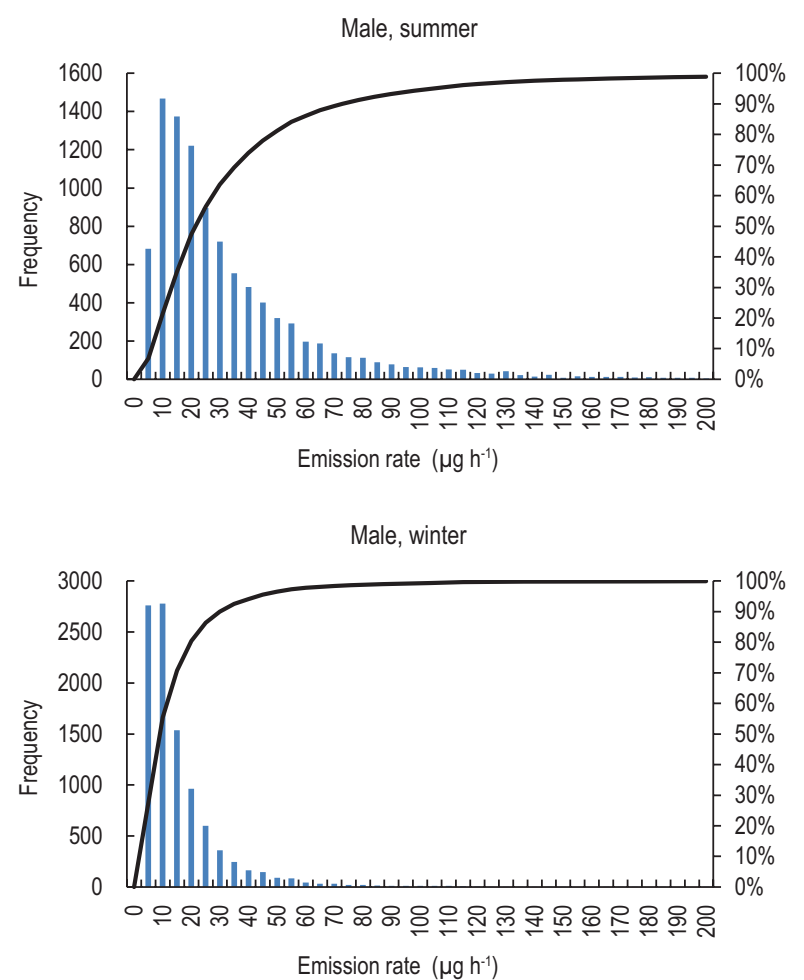
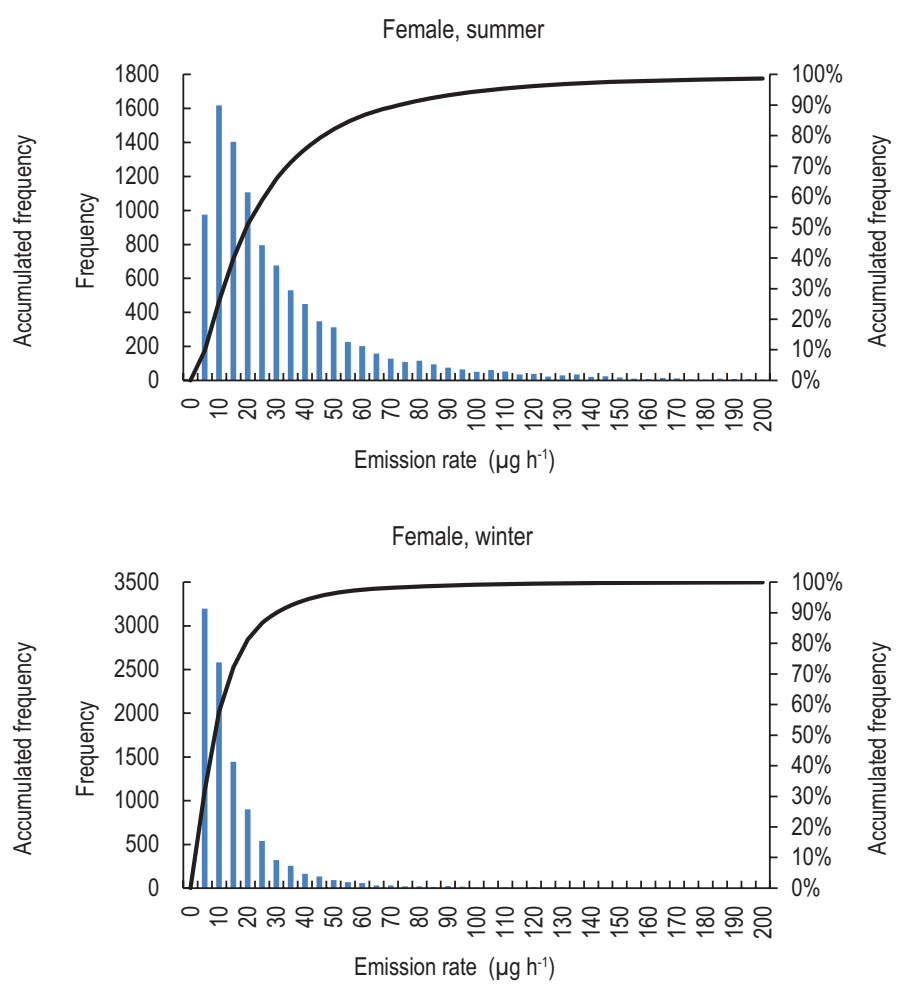

Fig.3 Histograms of estimated emission rate of acetaldehyde emanating from human skin surface derived by actual PFS-based emission flux data of 60 volunteers conducted by Sekine et al.(2007), surface body areas and exposure rates (Monte Carlo simulation, $n=10,000$ ) 


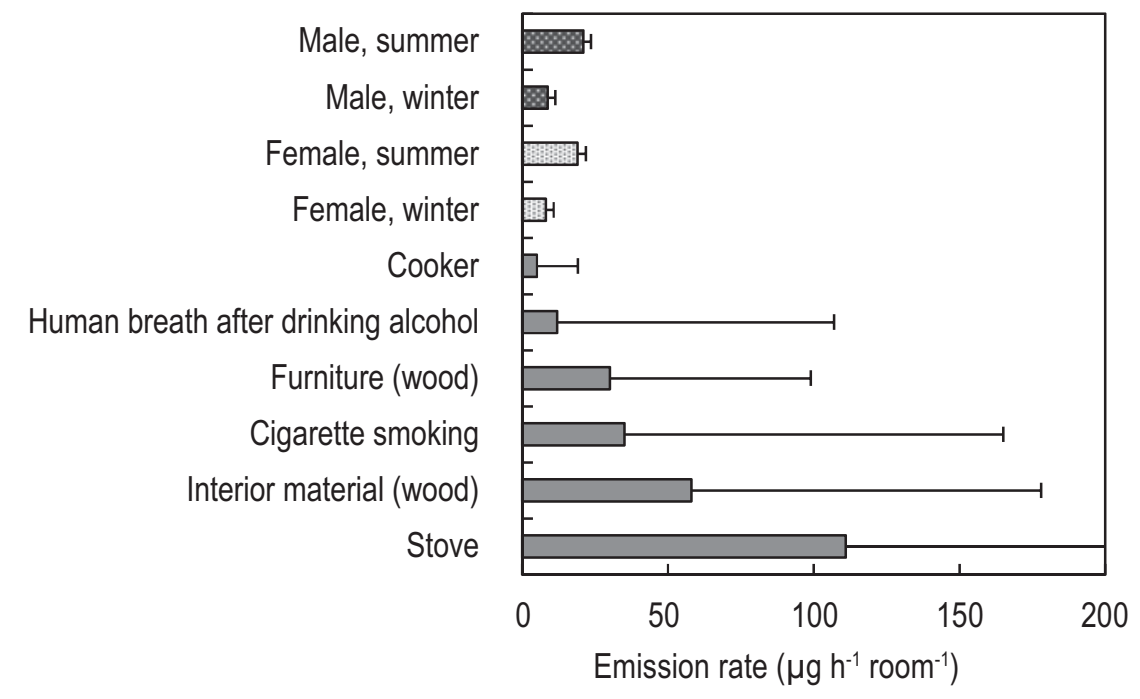

Fig.4 Estimated emission rates of acetaldehyde from the surface of human skin, comparing with those of other possible sources ${ }^{16)}$ in a room
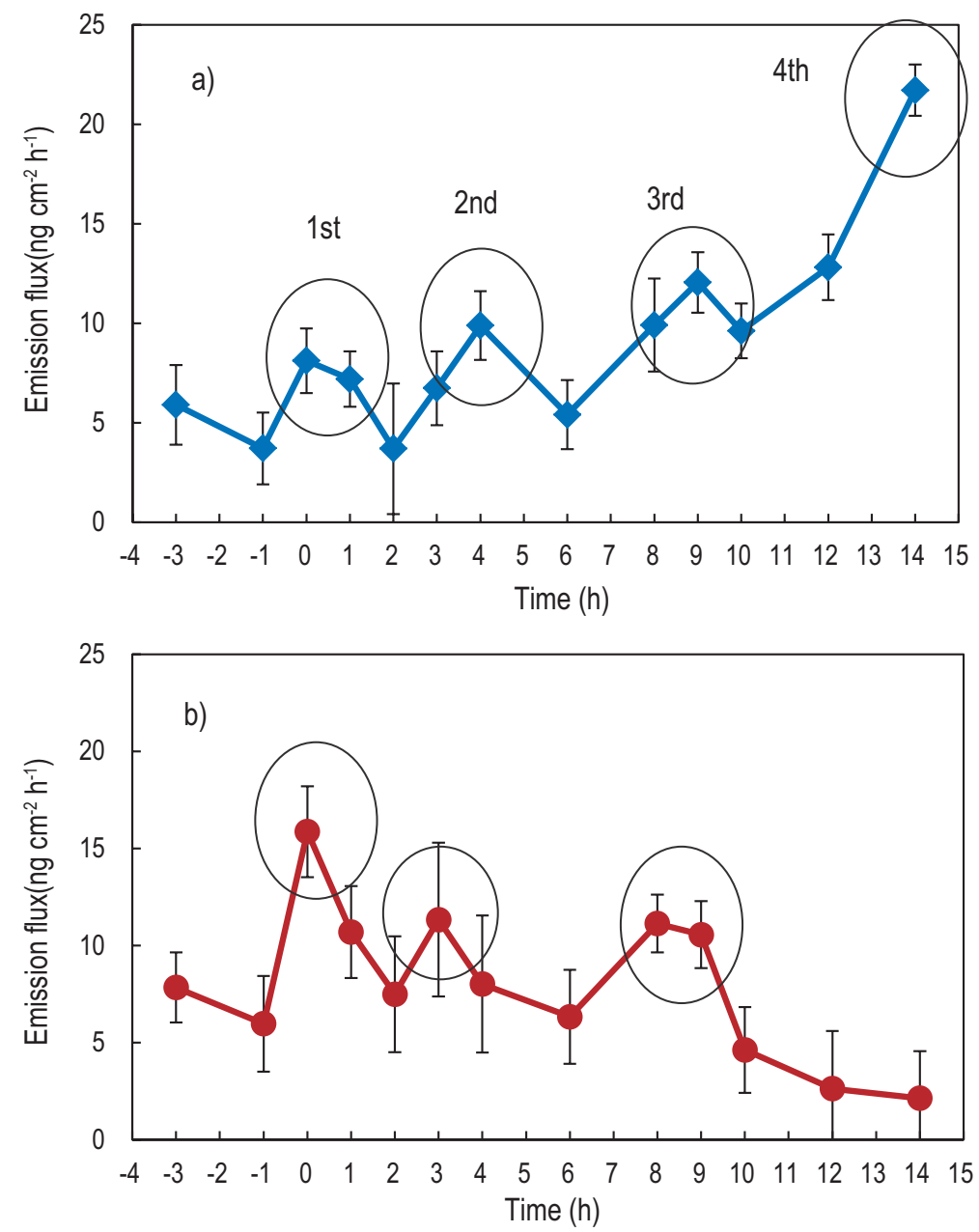

Fig.5 Variations of emission fluxes of acetaldehyde emanating human skin before and after drinking alcohol; a) drinking after meal, b) drinking after meal with a turmeric drink. Plots show geometric means of emission fluxes and error bars show geometric standard deviations of measurements for 8 volunteers 
直後(図中0時間のプロット)に平均值は増加し, 以 後増減を繰り返し，概ね4つのピークが観測された。 飲酒に伴う血液中のアセトアルデヒド濃度の経時変 化は二峰性を示すことが報告されており, 血中アル コールの肝外代謝, 非酵素的酸化および排泄等を反 映した一つ目のピーク ${ }^{17)}$ と, 胃や小腸で吸収された エタノールが肝臓で代謝されアセトアルデヒドおよ び酢酸を生成し, 血中へ流出して現れる二つ目のピー ク ${ }^{18)}$ がある。Fig.5(a)で観測されたピークは，これ ら血中濃度の変化に追随していると考えられるが, 血中濃度とは異なり，ピークは4つ見られた。これ らは, 血液中から揮発して皮膚表面に現れる二つの ピーク(第1と第2または第3), 血液から汗腺に移行 した画分が, 皮膚内移動により遅延しながら, 発汗 に伴い皮膚表面に現れる二つのピーク（第2または 第3 第4)から構成されている可能性があり, 皮膚 ガスの固有の経時変化と考えられる。尚, ALDH2 型による有意な差異は今回の測定結果では見いだせ なかった。一方, 飲酒直後から14時間後までの各測 定時間の放散フラックスは, 飲酒 1 時間前の值を 基準とすると $1.7 〜 5.1$ 倍であり，単純平均すると2.6 倍となった。この増加率(2.6倍)を用いて, 夏・冬 を想定した服装で男性もしくは女性1名が在室した 場合の放散速度は, 21〜 55 $\mu \mathrm{g} \mathrm{h}^{-1}$ となり, 最も高い 值を示す夏季・男性の放散速度は, 飲酒後の呼気か らの放散速度の4.6倍, 木質系家具と同程度の 值を示した。また室内空気中アセトアルデヒド濃度 は, 夏季・男性1名が在室する場合, $2.9 \mu \mathrm{g} \mathrm{m}^{-3}$, 夏 季・女性1名では2.6 $\mu \mathrm{g} \mathrm{m}^{-3}$, 冬季・男性1名では $1.2 \mu \mathrm{g} \mathrm{m}^{-3}$, 冬季・女性1名では $1.1 \mu \mathrm{g} \mathrm{m}^{-3}$ となり, 室内濃度指針值 $\left(48 \mu \mathrm{g} \mathrm{m}^{-3}\right)$ の $2.3 \sim 6.0 \%$ に相当し た。また夏季の場合は, 臭気閾值 $\left(2.7 \mu \mathrm{g} \mathrm{m}^{-3}\right)$ と同 等レベルになり, 飲酒に伴って皮膚表面から放散さ れるアセトアルデヒドが居室の臭気源になる可能性 が示唆された。

Fig.5(b)は, ウコン飲料水摂取後に飲酒した場合 のアセトアルデヒド放散フラックスの経時变化を示 す。飲酒直後に放散フラックスが顕著に増加し(第1 のピーク), 飲酒1時間前の2.7倍となった。第2のピー クは, Fig.5(a)の場合と異なり, 第1のピークに比 ベて小さくなる傾向があり,さらに第4のピークは 観測されず，むしろ飲酒前よりも低水準になった。 ウコンは過度の飲酒による頭痛や吐き気などに対す る緩和効果などが示唆されているが, その肝機能に
対する作用については明確な実証はない ${ }^{19-20)}$ 。本研 究の目的は, ウコンの作用を明らかにすることでは ないが，少なくともウコン飲料水を摂取することに より, 血中アルコールの代謝を早めるか, あるいは アセトアルデヒドの血液からの揮発を促進し, 結果 的に飲酒時の皮膚からのアセトアルデヒド放散フラッ クスを減少させ，室内空気中濃度への寄与率を低減 させる可能性が示唆された。

\section{4. 結論}

これまで室内環境中のアセトアルデヒドの発生源 として考慮されてこなかった皮膚ガスに着目し， PFS法による実測に基づき，七ト皮膚由来のアセト アルデヒドが室内空気中濃度に及ぼす影響を定量的 に検討した。その結果, ヒト皮膚由来のアセトアル デヒドの放散速度は, 飲酒後の呼気に由来するアセ トアルデヒドの放散速度よりも大きく, 呼気よりも 重要な発生源であることがわかった。居室の在室者 1名を想定した場合，皮膚由来のアセトアルデヒド は，室内濃度指針值レベルに対しては0.87〜2.3\%の 寄与であったが，飲酒を伴う場合は居室の臭気源に なる可能性が示唆された。

今回，1部屋あたりの在室者を1名と想定したが， 在室者を複数想定し, 飲酒を伴う場合, 皮膚からの アセトアルデヒド放散速度は無視できないほど大き くなる。皮膚ガスは室内空気中アセトアルデヒドの 新たに着目すべき発生源の一つとして考慮する必要 がある。

\section{引用文献}

1）橋詰博行, 高島征助：汗中に分泌される微量物 質の臨床的意義, 医学のあゆみ, 208(13), 1067-1068.

2）植田秀雄, 小橋恭一：においと疾病一生体ガス 測定から何が拓けるか一，におい・かおり環境 学会誌, 36(5), 270-274(2005).

3）渡辺明治：呼気測定の内科的意義, 呼気生化学 一測定とその意義一, メディカルレビュー社, p.8-15 (1999).

4）戸谷誠之, 植田秀雄：呼気ガス成分測定法によ る「無侵襲」生体指標計測の意義と宇宙医学, メディカルレビュー社, p.16-20(1998).

5) Bernier U. R., Booth M. M. and Yost R. A.: Analysis of human skin emanations by gas chroma- 
tography/mass spectrometry 1 . Thermal desorption of attractants for the yellow fever mosquito (Aedes aegypti) from handled glass beads, Anal. Chem., 71 (1), 1-7 (1999).

6) Bernier U. R., Kline D.L., Barnard D.R., Schreck C. E. and Yost R. A.: Analysis of human skin emanations by gas chromatography/mass spectrometry. 2 . Identification of volatile compounds that are candidate attractants for the yellow fever mosquito (Aedes aegypti), Anal. Chem., 72 (4), 747-756 (2000).

7) Naitoh K., Tsuda T., Nose K., Kondo T., Takasu A. and Hirabayashi T.: New measurement of hydrogen gas and acetone vapor in gases emanating from human skin, Instr. Sci. Tec., 30, 267-280 (2002).

8）野瀬和利, 近藤孝晴, 荒木修喜, 津田孝雄 : 七 卜皮膚表面より放出されるアセトンガス量と血 中 $\beta$ 一ヒドロキシ酪酸濃度との相関, 分析化学, 54(2), 161-165(2005).

9) Nose K., Nunome Y., Kondo T., Araki S. and Tsuda T.: Identification of gas emanated from human skin: methane, ethylene, ethane, Anal Sci., 21 (6), 625628 (2005)

10) Fujii M., Shinohara N., Lim A., Kumagai K. and Yanagisawa Y.: A study on emission of phthalate esters from plastic materials using a passive flux sampler, Atmos. Environ., 37, 5495-5504 (2003).

11) Sekine Y., Toyooka S. and Watts S. F.: Determination of acetaldehyde and acetone emanating from human skin using a passive flux sampler -HPLC system, J. Chromatogr. B, 859, 201-207 (2007).

12) 公益社団法人におい・かおり環境協会ホーム ページ，技術資料集，嗅覚閾值

http://www.orea.or.jp/about/ThresholdsTable.html

13）日本建築学会：アセトアルデヒドによる室内空 気污染防止に関する濃度等基準 ・同解説,

AIJES-A004-2010, 丸善, p1-33(2010).

14）中西準子, 篠原直秀, 納屋聖人：詳細リスク評 価書シリーズ11アセトアルデヒド, 丸善, pp117-152(2007).

15）藏澄美仁，堀越哲美，土川忠浩，松原斎樹：日 本人の体表面積に関する研究, 日生気誌, 31(1), 5-29(1994).

16）小野一之：外傷・熱傷, Dokkyo J. Medical Sci., 34(3), 281-287(2007).

17）藤宮龍也, 大洞弓子, 古村節男, 山岡清：アル コール投与により生じる血中アセトアルデヒド の変化とモーメント解析, アルコール代謝と肝, 12, 6-11 (1992).

18）藤宮龍也，大洞弓子，古村節男：血中アセトア ルデヒドの体内動態—シアナマイドの影響一, アルコールと医学生物学, 13, 21-25(1993).

19）浜野拓也, 西学, 伊藤禎司, 海老原淑子, 渡邊 泰雄：ウコン抽出物が健常成人のアルコール代 謝に及ぼす影響の検討, 応用薬理, 72(1/2), 31-38 (2007).

20) Quintans L. N., Castro G. D. and Castro J. A.: Oxidation of ethanol to acetaldehyde and free radicals by rat testicular microsomes, Arch. Toxicol., 79 (1) 25-30 (2005). 